\title{
Effect of Integrated Nutrient Management and Dates of Sowing on Growth and Yield of Pearlmillet (Pennisetum glaucum)
}

\author{
N. Nalini*, K.P. Vani, K.B. Suneetha Devi, P. Surendra Babu and S. Narender Reddy \\ College of Agriculture, Professor Jayashankar Telangana State Agricultural University \\ Rajendranagar, Hyderabad, India \\ *Corresponding author:
}

\begin{tabular}{|l|l}
\hline \multicolumn{1}{c|}{} & A B S T R A C T \\
\cline { 2 - 3 } \multicolumn{1}{l|}{ Keyword s } & $\begin{array}{l}\text { A field experiment was carried out in Kharif season (2014-15 and 2015-16) at College } \\
\text { Farm, College of Agriculture, Professor Jayashankar Telangana State Agricultural }\end{array}$ \\
$\begin{array}{l}\text { Pearlmillet, INM } \\
\text { and Dates of sowing }\end{array}$ & $\begin{array}{l}\text { University (PJTSAU), Rajendranagar, Hyderabad, India, to evaluate the effect of sowing } \\
\text { dates and integrated nutrition on growth and productivity of kharif pearlmillet. } \\
\text { Experimental results revealed that pearl millet crop, out of the three INM main treatments, } \\
\text { 100\% RDF + press mud @ 2.5 tons ha-1 i.e., M3 and among dates of sowing, pearl millet } \\
\text { sown on June 30th (D2) improved the growth parameters viz., plant height, number of } \\
\text { tillers m-2 and dry matter production as well as yield attributes like ear head length, weight } \\
\text { of grains ear head-1 and 1000-grain weight which significantly resulted in highest grain, } \\
\text { straw yield, harvest index. }\end{array}$ \\
\hline $\begin{array}{l}\text { Accepted: } \\
\text { 24 November 2018 } \\
\text { 10 December 2018 }\end{array}$
\end{tabular}

\section{Introduction}

In India, pearl millet is the fifth most important cereal grain crop next to rice, wheat, maize and sorghum. Today, it is gaining more attention due to increasing evidence of less seasonal rainfall, terminal heat, frequent occurrence of extreme weather events coupled with scanty water resources. Pearl millet traditionally is an indispensable component dry-farming system and is considered as more efficient in utilization of soil moisture, with higher level of heat tolerance than sorghum and maize (Chaudhary and Gautam, 2007). Millets are mainly grown by marginal and small farmers. Low productivity is mainly due to inadequate nutrient supply. Non-judicious use of chemical fertilizers declines soil organic matter, physical-chemical properties, pollutes surface and ground water there by reducing its productivity (Singh, 2002). Besides, fertilizers are becoming costlier and difficult for the resource poor farmers to apply recommended dose of fertilizers. Under such condition, integrated nutrient management (INM) has assumed great importance and has vital significance for the maintenance of soil productivity.

The productivity of pearl millet is very low as compared to important pearl millet growing countries in world. It is, therefore, necessary to increase the production and productivity of 
pearl millet by adopting scientific innovations. Sowing very early in season may not be advantageous. Also delayed sowing invariably reduces crop yield. Sowing the crop at optimum time increases yield due to suitable environment at all the growth stages of the crop. Flowering is induced after sufficient vegetative growth. Moisture stress or dry spells may be avoided during critical growth stages. Therefore, optimum sowing time plays an important role in pearl millet crop production.

\section{Materials and Methods}

The study was conducted during kharif with geographically situated at $17^{0} 19^{\prime} \mathrm{N}$ Latitude, $78^{0} 28^{\prime}$ E Longitude and at an altitude of 542.3 $\mathrm{m}$ above mean sea level. According to Troll's climatic classification, it falls under semi-arid tropics. The soil of experimental site was sandy clay loam with $\mathrm{pH} 7.6$, electrical conductivity $0.88 \mathrm{dSm}^{-1}$, low organic carbon $(0.44 \%)$, low available nitrogen $\left(217 \mathrm{~kg} \mathrm{ha}^{-1}\right)$ and medium phosphorus $\left(60 \mathrm{~kg} \mathrm{ha}^{-1}\right)$ and high in potassium (307 kg ha ${ }^{-1}$ ). The experiment was laid out in strip plot design with three main treatments (INM) and four subtreatments (dates of sowing), replicated thrice. The three main treatments (INM) were $\mathrm{M}_{1}$ $100 \%$ RDF, M $2-100 \%$ RDF + FYM @ 5 t $\mathrm{ha}^{-1}$ and $\mathrm{M}_{3}-100 \% \mathrm{RDF}+$ Press mud @ $2.5 \mathrm{t}$ $\mathrm{ha}^{-1}$. The recommended doses of fertilizer (RDF) i.e., 60:30:20 kg NPK ha ${ }^{-1}$ was applied through urea, single super phosphate (SSP) and murate of potash (MOP) respectively, Sub treatments: Dates of sowing (4) $D_{1}-$ June $15^{\text {th }}$, $\mathrm{D}_{2}-$ June $30^{\text {th }}, \mathrm{D}_{3}-$ July $15^{\text {th }}$ and $\mathrm{D}_{4}-$ July $30^{\text {th. }}$

\section{Results and Discussion}

As per the results shown in table 1, 2 and 3 the two factors significantly affected the response measurements either individually (main treatment effects and sub treatment effect). Integrated nutrient management and dates of sowing showed significant variation with all the growth and yield characters individually but interaction effect of all the parameters of pearl millet crop as influenced by integrated nutrient management and dates of sowing was found to be non significant in all crop growth stages.

\section{Effects on growth characters}

\section{Effect of integrated nutrient management}

\section{Growth characters}

Integrated nutrient management has a significant effect on the growth characters in both the years. Plant height, number of tillers $\mathrm{m}-2$ and dry matter production $\left(\mathrm{kg} \mathrm{ha}^{-1}\right)$ were significantly higher with the $\mathrm{M}_{3}(100 \% \mathrm{RDF}$ + press mud @ $2.5 \mathrm{t} \mathrm{ha}^{-1}$ ) than those in the $\mathrm{M}_{2}$ (100\% RDF + FYM @ $\left.5 \mathrm{t} \mathrm{ha}^{-1}\right)$ and 100\% RDF in both years (Table 1).

\section{Yield parameters}

Among the different integrated nutrient management treatments $\mathrm{M}_{3}$ i.e., $(100 \% \mathrm{RDF}$ + press mud @2.5 $\mathrm{t} \mathrm{ha}^{-1}$ ) significantly recorded higher ear head length $(\mathrm{cm})$ of 23 and $25.4 \mathrm{~cm}$ during 2014 and 2015, respectively as compared to other treatments. Whereas, the lower value of ear head length (23 and $25.4 \mathrm{~cm}$ ) was observed with $100 \%$ RDF treated plots with no organic manure. Application of $100 \%$ RDF + press mud @ 2.5 $\mathrm{t} \mathrm{ha}^{-1}\left(\mathrm{M}_{3}\right)$ produced maximum weight of grain ear head ${ }^{-1}$ (14.3 and $\left.16.8 \mathrm{~g}\right)$ as well as 1000-grain weight (5.97 and $7.54 \mathrm{~g}$ ) which was significantly higher over other two main treatments during 2014 and 2015 (Table 2).

\section{Yield}

Pearl millet grain and straw yields differed significantly because of integrated nutriment management in both years. The highest seed, biological yield and harvest index were 
recorded with the application of $\mathrm{M}_{3}$ i.e., (100 \% RDF + press mud @ $2.5 \mathrm{t} \mathrm{ha}^{-1}$ ), which was significantly superior to the application of $\mathrm{M}_{2}$ i.e., $\left(100 \% \mathrm{RDF}+\mathrm{FYM} @ 5 \mathrm{t} \mathrm{ha}^{-1}\right)$ and $100 \%$ RDF during both years (Table 3 ).

\section{Effect of date of sowing}

Growth characters: Pearl millet growth characters viz., plant height, number of tillers $\mathrm{m}^{-2}$ and dry matter production $\left(\mathrm{kg} \mathrm{ha}^{-1}\right)$ were significantly affected by different dates of sowing.

During the first year, these growth characters were higher with $30^{\text {th }}$ June sown crop and significantly superior to the $15^{\text {th }} \mathrm{July}, 15^{\text {th }}$ June and $30^{\text {th }}$ July sown crops (Table 1). Similar results were reported in the second year.

Table.1 Effect of INM and dates of sowing on growth parameters of pearl millet

\begin{tabular}{|c|c|c|c|c|c|c|}
\hline \multirow[t]{2}{*}{ Treatments } & \multicolumn{2}{|c|}{$\begin{array}{l}\text { Plant height } \\
\quad(\mathrm{cm})\end{array}$} & \multicolumn{2}{|c|}{$\begin{array}{l}\text { No. of tillers } \\
\left(\mathrm{m}^{-2}\right)\end{array}$} & \multicolumn{2}{|c|}{$\begin{array}{c}\text { Dry matter } \\
\text { production }\left(\mathrm{kg} \mathrm{ha}^{-1}\right)\end{array}$} \\
\hline & 2014 & 2015 & 2014 & 2015 & 2014 & 2015 \\
\hline \multicolumn{7}{|l|}{ Main treatments (INM) } \\
\hline $\mathrm{M}_{1}-100 \% \mathrm{RDF}$ & 126.0 & 130.4 & 22.1 & 24.7 & 6249 & 6449 \\
\hline $\begin{array}{l}M_{2^{-100} \% \text { RDF + FYM }} \text { @ } 5 \mathrm{t} \mathrm{ha}^{-1} \\
\end{array}$ & 138.7 & 144.2 & 24.8 & 27.6 & 7038 & 7238 \\
\hline $\begin{array}{l}\mathrm{M}_{3}-100 \% \text { RDF + } \\
\text { Pressmud @ } 2.5 \text { tha }^{-1} \\
\end{array}$ & 151.0 & 155.6 & 28.0 & 31.8 & 7737 & 7937 \\
\hline SE $\mathrm{m}( \pm)$ & 2.6 & 2.3 & 0.56 & 0.71 & 202 & 270 \\
\hline $\mathrm{CD}(\mathrm{P}=0.05 \%)$ & 10.2 & 8.9 & 2.19 & 2.69 & 687 & 936 \\
\hline \multicolumn{7}{|c|}{ Sub treatments (Dates of Sowing) } \\
\hline $\mathrm{D}_{1}-$ June $15^{\mathrm{th}}$ & 131.6 & 134.9 & 24.0 & 26.9 & 6562 & 6762 \\
\hline $\mathrm{D}_{2}-$ June $30^{\text {th }}$ & 159.4 & 164.7 & 28.1 & 31.6 & 8205 & 8405 \\
\hline $\mathbf{D}_{3}-$ July $15^{\text {th }}$ & 150.9 & 155.8 & 26.0 & 28.6 & 7480 & 7680 \\
\hline $\mathrm{D}_{4}-$ July $30^{\text {th }}$ & 112.2 & 118.3 & 21.8 & 25.1 & 5784 & 5984 \\
\hline SE $m( \pm)$ & 2.4 & 2.8 & 0.50 & 0.83 & 221 & 213 \\
\hline $\mathrm{CD}(\mathrm{P}=0.05 \%)$ & 8.3 & 9.8 & 1.74 & 1.97 & 763 & 745 \\
\hline \multicolumn{7}{|l|}{ Interaction effect } \\
\hline \multicolumn{7}{|l|}{ Main at same level of sub } \\
\hline SE $\mathbf{m}( \pm)$ & 4.9 & 4.0 & 1.3 & 1.8 & 222 & 331 \\
\hline $\mathrm{CD}(\mathrm{P}=0.05 \%)$ & NS & NS & NS & NS & NS & NS \\
\hline \multicolumn{7}{|l|}{ Sub at same level of Main } \\
\hline SE $\mathbf{m}( \pm)$ & 4.4 & 3.6 & 1.1 & 1.6 & 210 & 317 \\
\hline $\mathrm{CD}(\mathrm{P}=0.05 \%)$ & NS & NS & NS & NS & NS & NS \\
\hline
\end{tabular}


Table.2 Effect of INM and dates of sowing on yield attributes of pearl millet

\begin{tabular}{|c|c|c|c|c|c|c|}
\hline \multirow[t]{2}{*}{ Treatments } & \multicolumn{2}{|c|}{$\begin{array}{l}\text { Ear head length } \\
\qquad(\mathrm{cm})\end{array}$} & \multicolumn{2}{|c|}{$\begin{array}{l}\text { Weight of grain } \\
\text { (g)/ear head }\end{array}$} & \multicolumn{2}{|c|}{1000 grain weight $(\mathrm{g})$} \\
\hline & 2014 & 2015 & 2014 & 2015 & 2014 & 2015 \\
\hline \multicolumn{7}{|l|}{ Main treatments (INM) } \\
\hline $\mathrm{M}_{1}-\mathbf{1 0 0} \% \mathrm{RDF}$ & 18.3 & 20.9 & 11.7 & 14.3 & 4.29 & 5.39 \\
\hline $\begin{array}{l}\mathrm{M}_{2}-100 \% \mathrm{RDF}+\mathrm{FYM} \\
\text { @ } 5 \mathrm{t} \mathrm{ha}^{-1}\end{array}$ & 20.6 & 23.1 & 12.9 & 15.4 & 5.27 & 6.62 \\
\hline $\begin{array}{l}\mathbf{M}_{3}-100 \% \mathrm{RDF}+ \\
\text { Pressmud @ } 2.5 \mathrm{tha}^{-1}\end{array}$ & 23.0 & 25.4 & 14.3 & 16.8 & 5.97 & 7.54 \\
\hline SE m ( $( \pm)$ & 0.5 & 0.4 & 0.42 & 0.34 & 0.08 & 0.15 \\
\hline $\mathrm{CD}(\mathrm{P}=\mathbf{0 . 0 5 \%})$ & 1.8 & 1.6 & 1.25 & 1.02 & 0.31 & 0.44 \\
\hline \multicolumn{7}{|c|}{ Sub treatments (Dates of Sowing) } \\
\hline$D_{1}-$ June $15^{\text {th }}$ & 19.6 & 22.0 & 12.4 & 14.9 & 4.64 & 5.79 \\
\hline $\mathrm{D}_{2}-$ June $30^{\text {th }}$ & 24.9 & 27.1 & 14.7 & 17.7 & 6.32 & 8.00 \\
\hline $\mathbf{D}_{3}-$ July $15^{\text {th }}$ & 22.3 & 24.8 & 13.6 & 16.3 & 5.74 & 7.48 \\
\hline $\mathrm{D}_{4}-\mathrm{July} 30^{\text {th }}$ & 15.8 & 18.5 & 11.2 & 13.2 & 4.01 & 4.80 \\
\hline SE m $( \pm)$ & 0.4 & 0.5 & 0.40 & 0.54 & 0.09 & 0.15 \\
\hline $\mathrm{CD}(\mathrm{P}=\mathbf{0 . 0 5 \%})$ & 1.5 & 1.8 & 1.05 & 1.40 & 0.32 & 0.41 \\
\hline \multicolumn{7}{|l|}{ Interaction effect } \\
\hline \multicolumn{7}{|l|}{ Main at same level of sub } \\
\hline SE m ( \pm$)$ & 0.55 & 0.90 & 1.15 & 1.01 & 0.15 & 0.16 \\
\hline $\mathrm{CD}(\mathrm{P}=\mathbf{0 . 0 5 \%})$ & NS & NS & NS & NS & NS & NS \\
\hline \multicolumn{7}{|l|}{ Sub at same level of Main } \\
\hline SE m ( $( \pm)$ & 0.55 & 0.90 & 1.15 & 1.01 & 0.15 & 0.16 \\
\hline $\mathrm{CD}(\mathrm{P}=\mathbf{0 . 0 5 \%})$ & NS & NS & NS & NS & NS & NS \\
\hline
\end{tabular}


Table.3 Effect of INM and dates of sowing on grain and straw yield $\left(\mathrm{kg} \mathrm{ha}^{-1}\right)$ and harvest index (\%) of pearl millet

\begin{tabular}{|c|c|c|c|c|c|c|}
\hline \multirow[t]{2}{*}{ Treatments } & \multicolumn{2}{|c|}{ Grain yield } & \multicolumn{2}{|c|}{ Straw yield } & \multicolumn{2}{|c|}{ HI } \\
\hline & 2014 & 2015 & 2014 & 2015 & 2014 & 2015 \\
\hline \multicolumn{7}{|l|}{ Main treatments (INM) } \\
\hline $\mathrm{M}_{1}-100 \% \mathrm{RDF}$ & 1985 & 2207 & 3506 & 3712 & 36.0 & 36.8 \\
\hline $\begin{array}{l}\mathrm{M}_{2}-100 \% \mathrm{RDF}+\mathrm{FYM} \\
\quad \text { @ } 5 \mathrm{t} \mathrm{ha}^{-1}\end{array}$ & 2483 & 2704 & 4323 & 4607 & 36.7 & 37.3 \\
\hline $\begin{array}{l}\mathrm{M}_{3}-100 \% \mathrm{RDF}+ \\
\text { Pressmud @ } 2.5 \mathrm{t} \mathrm{ha}\end{array}$ & 3055 & 3274 & 5121 & 5314 & 37.7 & 38.3 \\
\hline SE $m( \pm)$ & 95 & 97 & 132 & 138 & 1.0 & 1.2 \\
\hline $\mathrm{CD}(\mathrm{P}=0.05 \%)$ & 374 & 380 & 517 & 542 & NS & NS \\
\hline \multicolumn{7}{|c|}{-Sub treatments (Dates of Sowing) } \\
\hline$D_{1}-$ June $15^{\text {th }}$ & 2343 & 2459 & 4060 & 4205 & 36.6 & 37.0 \\
\hline$D_{2}-$ June $30^{\text {th }}$ & 3047 & 3437 & 5221 & 5499 & 37.2 & 38.8 \\
\hline$D_{3}-$ July $15^{\text {th }}$ & 2740 & 3004 & 4705 & 4929 & 37.0 & 38.2 \\
\hline $\mathbf{D}_{4}-$ July $30^{\text {th }}$ & 1900 & 2013 & 3281 & 3544 & 36.6 & 35.8 \\
\hline SE $\mathbf{m}( \pm)$ & 88 & 116 & 144 & 159 & 1.2 & 1.2 \\
\hline $\mathrm{CD}(\mathrm{P}=0.05 \%)$ & 305 & 402 & 499 & 549 & NS & NS \\
\hline \multicolumn{7}{|l|}{ Interaction effect } \\
\hline \multicolumn{7}{|l|}{ Main at same level of sub } \\
\hline SE $m( \pm)$ & 258 & 279 & 264 & 443 & 2.1 & 3.1 \\
\hline $\mathrm{CD}(\mathrm{P}=0.05 \%)$ & NS & NS & NS & NS & NS & NS \\
\hline \multicolumn{7}{|l|}{ Sub at same level of Main } \\
\hline $\operatorname{SE} \mathbf{m}( \pm)$ & 207 & 263 & 235 & 363 & 1.9 & 2.6 \\
\hline $\mathrm{CD}(\mathrm{P}=0.05 \%)$ & NS & NS & NS & NS & NS & NS \\
\hline
\end{tabular}

\section{Yield parameters}

Similarly, significantly higher values of ear head length, weight of grain per ear head and 1000 grain weight (test weight $(\mathrm{g})$ ) were recorded for $30^{\text {th }}$ June sown crop in both the years, whereas lowest values of these characters were recorded for $30^{\text {th }}$ July sown crop in both the years (Table 2).

\section{Yield}

Sowing dates showed significant effects on seed and biological yield of pearl millet in 
both the years (Table 3). Grain yield (3047 and $3437 \mathrm{~kg} \mathrm{ha}^{-1}$ ), straw yield (5221 and 5499 $\mathrm{kg} \mathrm{ha}^{-1}$ ) and harvest index (37.2 and $38.8 \%$ ) of pearl millet was found significantly higher with June $30^{\text {th }}\left(\mathrm{D}_{2}\right)$ over rest of the sowing dates during 2014 and 2015.

Improvement in growth characters is considered to be pre-requisite to increased yield of any crop. Significant effect on the increase on the plant height with the application of NPK may be attributed to the fact that nitrogen being an essential constituent of plant tissue favours rapid cell division and its enlargement, which together with the adequate quantity of phosphorus and potassium helps in the rapid cell division and better development of the cell size. Further, the beneficial effect of FYM and press mud may be attributed to the fact that it supplied available plant nutrients and had solubilizing effect on fixed forms of nutrients thus making the nutrients available for increased intermodal length thus improving plant height and dry matter production of crop. These results are in conformity with Khan et al., (2000).

The beneficial effect of yield attributes might also be due to the supply of all the essential nutrients by press mud and FYM that might have resulted in higher manufacture of food and its subsequent partitioning of photosynthates towards sink. The significant increase in test weight may be attributed to better grain filling and bold sized seed due to improved nutrient supply. The results are corroborative to those reported by Patel et al., (2014). The application of pressmud compost to agricultural fields is likely to improve soil health by adding macro and micronutrients and organic matter to soil ultimately leads to crop productivity by increased the quality of grains by increasing the protein and $\mathrm{Ca}$ contents, similar results confirmed by Mishra et al., 1982.
All the growth parameters were influenced owing to different date of sowing. This was probably due to better growth environment caused by slightly lower temperature and better soil moisture regime. Time of sowing also plays an important role to fully exploit the genetic potentiality of variety as it provides optimum growing conditions such as temperature, light, humidity and rainfall. Sowing date determines the time available for vegetative phase before the onset of flowering, which is mainly influenced by the photoperiod. The growth duration although has not affected the elongation (height) but was reflected in the number of branches per plant. Increase in plant height, tillers $\mathrm{m}^{-2}$ and dry matter production with June $30^{\text {th }}$ sowing date which may be due to enjoying relatively more time by the plant and sufficient rainfall in the growing season, which favoured more vegetative growth of the crop. Optimum sowing time i.e., June $15^{\text {th }}$ of pearl millet crop by prolonged photoperiod at vegetative growth resulting in maximum ear head length, higher grain weight and higher test weight as compared to early and late sowing dates. These results are in agreement with those reported by Jan et al., (2015) The higher grain and straw yield and harvest index with June $30^{\text {th }}$ sowing was probably due to good seed set favored by warm weather prevailed during at maturity. Similar results were reported by Maurya et al., (2016).

In conclusion, the study revealed that crop sown on $30^{\text {th }}$ June with application of, $100 \%$ RDF with press mud @ $2.5 \mathrm{t} \mathrm{ha}^{-1} \mathrm{had}$ maximum plant height, number of tillers, dry matter production, grain and straw yield by pearl millet.

\section{References}

Chaudhary, R. S and Gautham, R. C. 2007. Effect of nutrient management practices on 
growth and yield of pearl millet (Pennisteum glaucum). Indian Journal of Agronomy.

52 (1): 64-66.

Jan, A., Khan, I., Ali, S., Amir, A and Sohail. 2015. Sowing dates and sowing methods influenced on growth, yield and yield components of pearl millet under rainfed conditions. Journal of Environment and Earth Science. 5 (1): 105-109.

Khan, H., Jain, P. C and Trivedi, S. K. 2000. Nutrient management in pearl millet (Pennisetum glaucum) under rainfed condition. Indian Journal of Agronomy. 45: 728-721.

Maurya, S. K., Nath, S., Patra, S. S and Rout, S. 2016. Effect of different sowing dates on growth and yield of pearlmillet (Pennisetum glaucum L.) varieties under Allahabad condition. International Journal of Science and Nature. 7 (1): 62-69.

Mishra MM, Kapoor KR, Yadav KS. Effects of compost enriched with mussoorie rock phosphate on crop yield. Indian Journal of Agricultural Science, 1982; 52(10):674-678.

Patel, P. R., Patel, B. J., Vyas, K. G and Yadav, B. G. 2014. Effect of integrated nitrogen management and bio-fertilizer in kharif pearl millet (Pennisetum glaucum L.). Advance Research Journal of Crop Improvement. 5 (2): 122-125.

Singh, S. R. 2002. Effect of organic farming on productivity and quality of French bean (Phaseolus vulgaris L.). Legume Research. 25 (2):124-126.

\section{How to cite this article:}

Nalini, N., K.P. Vani, K.B. Suneetha Devi, P. Surendra Babu and Narender Reddy, S. 2018. Effect of Integrated Nutrient Management and Dates of Sowing on Growth and Yield of Pearlmillet (Pennisetum glaucum). Int.J.Curr.Microbiol.App.Sci. 7(12): 3165-3171. doi: https://doi.org/10.20546/ijcmas.2018.712.364 